\title{
MANAGEMENT OF WASTE WATER TO VERMICELLI PRODUCTION IN DONG THO VILLAGE, THAI BINH, VIETNAM
}

\author{
Pham Thi To Oanh \\ Vietnam Cooperative Alliance
}

\begin{abstract}
Dong Tho is a commune of Thai Binh City in Thai Binh province, Vietnam. The major occupation is the production of vermicelli which is made from edible canna. The pollution characteristic of Dong Tho commune is the waste water originated from production process. Water pollution is indicated by the indicators such as TSS, COD, BOD 5 are many times higher than the (QCVN 40: 2011/ BTNMT). Specifically, TSS is 5.8 times higher, COD is 1.70 times higher and BOD $_{5}$ is 3.28 times higher than the permitted standards. Acidic $\mathrm{pH}$ in waste water only reached 5.3. Interview of local people also important base to assess poluttion level. Methods are used such as methods of collecting and synthesizing data, investigation and fieldwork, analytical methods in the laboratory, statistical methods, data processing, mapping method. With the current pollution situation in Dong Tho vermicelli village, the research proposes some management solutions and techniques of biological waste water treatment. The biological treatment is suitable for local conditions and feasibility, helps to manage, prevent, and reduce environmental pollution of the waste water originated from production process, improve the environment of the village.
\end{abstract}

Keywords: pollution; village; discharge; waste water; Thai Binh.

Ngày nhận bài: 22/02/2020; Ngày hoàn thiện: 29/02/2020; Ngày đăng: 29/02/2020

\section{QUẢN LÝ NƯỚC THẢI SẢN XUẤT MIẾN TẠI LÀNG NGHỀ ĐÔNG THỌ, THÁI BİNH, VIẸT NAM}

\author{
Phạm Thị Tố Oanh \\ Liên minh Hợp tác xã Việt Nam
}

\section{TÓM TẮT}

Đông Thọ là một xã thuộc thành phố Thái Bình, tỉnh Thái Bình. Với nghề phụ chủ yếu là sản xuất miến dong. Đặc trưng ô nhiễm của Đông Thọ là nước thải sản xuất. Các chỉ tiêu ô nhiễm như TSS, COD, BOD 5 đều cao hơn tiêu chuẩn QCVN 40: 2011/ BTNMT. Đặc biệt, TSS cao hơn 5,8 lần, $\mathrm{COD}$ cao hơn 1,7 lần và $\mathrm{BOD}$ cao hơn 3,28 lần tiêu chuẩn cho phép. $\mathrm{pH}$ chỉ đạt 5,3 . Ngoài ra, kết quả nghiên cứu đánh giá mức độ ô nhiễm dựa trên cả phỏng vấn người dân. Các phương pháp sử dụng trong nghiên cứu là thu thu thập, tổng hợp số liệu; điều tra, khảo sát thực địa; phân tích trong phòng thí nghiệm; thống kê, xử lý số liệu; bản đồ.Với thực trạng ô nhiễm hiện nay tại làng nghề sản xuất miến Đông Thọ, đồng thời nhận thức của người dân địa phương cũng như chính quyền địa phương, nghiên cứu này nhằm đưa ra một số giải pháp trong quản lý và công nghệ xử lý nước thải bằng biện pháp sinh học. Xử lý sinh học là biện pháp phù hợp đặc điểm ô nhiễm tại khu vực nghiên cứu, có tính khả thi cao nhằm hỗ trợ trong quản lý, phòng ngừa và giảm ô nhiễm môi trường của nước thải phát sinh trong quá trình sản xuất, cải thiện môi trường làng nghề.

Từ khóa: Ô nhiếm; làng mạc; xả thải; nước thải; Thái Bình.

Received: 22/02/2020; Revised: 29/02/2020; Published: 29/02/2020

Email: oanhphamto@gmail.com

https://doi.org/10.34238/tnu-jst.2020.02.2699

http://jst.tnu.edu.vn; Email: jst@tnu.edu.vn 


\section{Introduction}

Water plays a very important role in the existence and development of humans and all living things on earth. In the production process as well as daily life, along with the increase in the human population, people have used and discharged a large amount of waste water into the environment. Waste water in general has many types depending on the sources generated, but one type of sewage which is now seriously polluted and of great concern is production waste water. The manmade waste water generated during production is only partly treated and most of it has not been treated thoroughly and discharged directly to the surrounding environment, causing water pollution [1].

Besides, the community's role in production waste water management is enormous. Communities participating in environmental protection will make all subjects in society see their role and responsibility in preserving and protecting the environment. Thereby, creating habits, building a life in an environmentally friendly way, contributing to sustainable social development, is the concretiation of guidelines, policies and state laws on the management and treatment of production waste water into people's lives.

Dong Tho is a commune of Thai Binh city, Thai Binh province. With the secondary occupation of vermicelli production, besides the economic benefits, the expansion of vermicelli production villages in Dong Tho commune also increases the amount of waste generated. Polluted characteristic of Dong Tho is production waste water. The communal government has received feedback and concern from the surrounding communes and local people were annoyed... Moreover, Dong Tho commune is on a journey to build a new countryside, so the issue of green - clean - beautiful environment, safe production and business are being paid great attention [2].

It is necessary to have solution to treatment of waste water in Dong Tho traditional village, Thai Binh city.

\section{Research method}

This research collected data on natural and socio-economic conditions of Dong Tho commune, available data on water quality of surrounding areas of Dong Tho commune. Consulting the authorities and the community about information on the current state of the environment, management structure and environmental management organization in Dong Tho commune. Moreover, taking water samples at the study area, preserving samples as prescribed; analysis of locally collected wastewater samples. Using complete documents to map the locations of the study area to. Using Mapinfo software tools to assess the environmental status.

\section{Results and discussion}

Dong Tho is a river suburban commune, located in the north of Thai Binh city, formerly the south of Dong Hung district. Dong Hung district is located in the center of Thai Binh province. The total natural area of the district is about $198.4 \mathrm{~km}^{2}$.

Dong Tho commune borders Dong Duong commune - Dong Hung commune in the north, Dong My commune in the east, Tra Ly river in the west and Dong Hoa commune in the south.

Dong Tho commune, Thai Binh city, Thai Binh province has a vermicelli production occupation for a long time so it cannot avoid water pollution. Dong Tho has six production hamlets such as Doan Ket, Hong Phong, Thong Nhat, Quang Trung, Tran Phu, Lam Son. Study areas are shown in Figure 1.

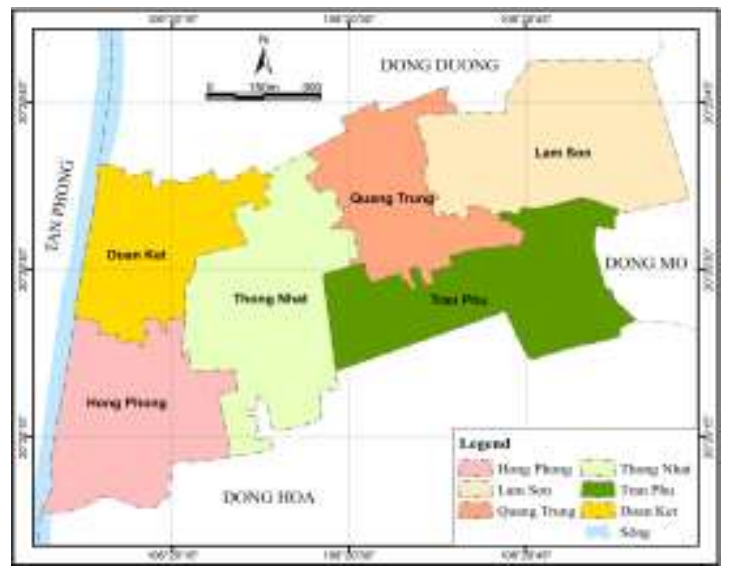

Figure 1. Location of the study area 
Because in the process of producing arrowroot vermicelli, the largest amount of waste water is discharged to the environment from the starch making stages with very high organic content, so the problem of water pollution in vermicelli production villages is quite serious. In production households, due to their spontaneous development and limited investment conditions, it is almost nonexistent to invest in waste water treatment systems before being discharged into the environment. Compact waste water is discharged directly into the environment, causing heavy organic pollution in lakes and canals in the production area. The canals have not been dredged for a long time, stagnant of pollutants, the decomposition of organic matters takes place strongly, causing very uncomfortable smell. In addition, the amount of daily waste water is often discharged directly into the sewage canals, so the pollution is increasing. Groundwater shows signs of pollution, many criteria exceed the permissible standards.

Waste water is collected at various locations (NT). The specific analysis results as follows.

According to the survey data in table 1 and table 2 , on average, each day in the peak months, each household uses up to $30 \mathrm{~m}^{3}$ of water for production, with the amount of waste water accounting for $70 \%$ of the usage. The indicators such as TSS, $\mathrm{COD}, \mathrm{BOD}_{5}$ are many times higher than the (QCVN 40: 2011/ BTNMT). Specifically, TSS is 5.8 times higher, COD is 1.70 times higher and $\mathrm{BOD}_{5}$ is 3.28 times higher than the permitted standards. Acidic $\mathrm{pH}$ in waste water only reached 5.32, proving that the waste water is sour fermented.

Table 1. Analysis results of waste water samples for vermicelli production at producing facilities

\begin{tabular}{clccc}
\hline No. & \multicolumn{1}{c}{ Parameter } & Unit & Results & Vietnam standard 40 : 2011/BTNMT \\
\hline 1 & $\mathrm{pH}$ & - & 5.32 & $5.5-9$ \\
2 & $\mathrm{COD}$ & $\mathrm{mgO}_{2} / 1$ & 255 & 150 \\
3 & $\mathrm{BOD}_{5}\left(20^{\circ} \mathrm{C}\right)$ & $\mathrm{mgO}_{2} / 1$ & 164 & 50 \\
4 & ${\left.\text { Amoni }\left(\mathrm{NH}_{4}{ }^{+}\right) \text {(according to nitrogen }\right)}^{\mathrm{mg} / \mathrm{l}}$ & 7.15 & 10 \\
5 & Total nitrogen & $\mathrm{mg} / \mathrm{l}$ & 16.7 & 40 \\
6 & Total Phosphorus & $\mathrm{mg} / \mathrm{l}$ & 2.45 & 6 \\
7 & Floating solids (TSS) & $\mathrm{mg} / \mathrm{l}$ & 580 & 100 \\
\hline
\end{tabular}

(Source: Center of Science and Environment, VietnamCooperative Alliance, 2018)

Table 2. Results of some waste water samples in Dong Tho commune canals

\begin{tabular}{|c|c|c|c|c|c|c|c|c|c|c|}
\hline \multirow[t]{2}{*}{ No. } & \multirow[t]{2}{*}{ Criteria } & \multirow[t]{2}{*}{ Unit } & \multirow[t]{2}{*}{ NT1 } & \multirow[t]{2}{*}{ NT2 } & \multirow[t]{2}{*}{ NT3 } & \multirow[t]{2}{*}{ NT4 } & \multirow[t]{2}{*}{ NT5 } & \multirow[t]{2}{*}{ NT6 } & \multicolumn{2}{|c|}{$\begin{array}{c}\text { Vietnam standard } 40 \text { : } \\
\text { 2011/BTNMT }\end{array}$} \\
\hline & & & & & & & & & $\mathbf{A}$ & B \\
\hline 1 & Temperature & ${ }^{\circ} \mathrm{C}$ & 25.0 & 25.4 & 25.6 & 24.9 & 24.6 & 25 & 40 & 40 \\
\hline 2 & $\mathrm{pH}$ & - & 6.16 & 6.71 & 6.64 & 6.41 & 6.29 & 6.85 & $6-9$ & $5.5-9$ \\
\hline 3 & TSS & $\mathrm{mg} / \mathrm{l}$ & 320 & 151 & 145 & 205 & 259 & 29 & 50 & 100 \\
\hline 4 & COD & $\mathrm{mgO}_{2} / \mathrm{l}$ & 318 & 232 & 219 & 272 & 226 & 71 & 75 & 150 \\
\hline 5 & $\mathrm{BOD}_{5}\left(20^{\circ} \mathrm{C}\right)$ & $\mathrm{mgO}_{2} / 1$ & 165 & 115 & 145 & 130 & 140 & 40 & 30 & 50 \\
\hline 6 & Clorua $\left(\mathrm{Cl}^{-}\right)$ & $\mathrm{mg} / \mathrm{l}$ & 145 & 137 & 139 & 141 & 137 & 112 & 500 & 1000 \\
\hline 7 & $\begin{array}{l}\text { Amoni (according } \\
\text { to } \mathrm{N} \text { ) }\end{array}$ & $\mathrm{mg} / \mathrm{l}$ & 26.7 & 18.9 & 19,2 & 19.7 & 16.4 & 10.8 & 5 & 10 \\
\hline 8 & Total nitrogen & $\mathrm{mg} / \mathrm{l}$ & 31.4 & 27.6 & 26.1 & 28.2 & 24.6 & 16.1 & 20 & 40 \\
\hline 9 & Total Phosphorus & $\mathrm{mg} / \mathrm{l}$ & 4.23 & 3.59 & 3.16 & 3.72 & 2.97 & 2.09 & 4 & 6 \\
\hline
\end{tabular}

(Source: Center of Science and Environment, VietnamCooperative Alliance, 2018)

The air source in the vermicelli villages is also polluted by the sour smell from soaked arrowroot powder. To save costs, many production households take advantage of the final soaked water to soak the new powder. Due to long time without production immediately, the organic matter 
decomposes in water causing a sour smell, reducing the quality of air environment and causing unsure cleanliness, reducing product quality. Thong Nhat hamlet has 90 households and Doan Ket hamlet has 81 households producing vermicelli with large scale. The hamets of Tran Phu, Tan Phong, Lam Son and Hong Phong have smaller and medium-scale production with the number of households from 27-50 households per hamlet.

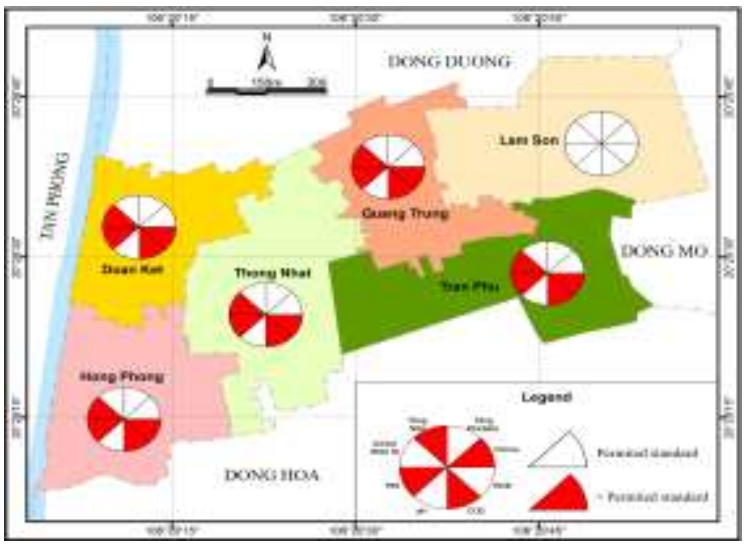

Figure 2. Current situation of production waste water pollution in Dong Tho commune

NT1: latitude $20^{\circ} 29^{\prime} 23,193 "$, longitude $106^{\circ}$ $20^{\prime}$ 4,512"; NM2: latitude $20^{\circ} 29^{\prime} 33,58^{\prime \prime}$, longitude $106^{\circ} 20^{\prime} 15,88^{\prime \prime}$; NT3: latitude $20^{\circ}$ $29^{\prime} 28,07^{\prime \prime}$, longitude $106^{\circ} 20^{\prime} 16,81^{\prime \prime}$, NT4: latitude $20^{\circ} 29^{\prime} 29,729 "$ ", longitude $106^{\circ} 20^{\prime}$ 35,233", NT5: latitude $20^{\circ} 29^{\prime} 34,661 "$, longitude $106^{\circ} 20^{\prime} 25,737 "$, NT6: latitude $20^{\circ}$ $29^{\prime} 48,828^{\prime \prime}$, longitude $106^{\circ} 20^{\prime} 30,736 "$.

Six represenrative sites were select to assess the quality of waste water origined from production, belong to six hamlets of Dong Tho. Current situation of production waste water pollution in six represenrative sites Dong Tho commune are shown in Figure 2.

Six represenrative sites were select to assess the quality of waste water origined from production.

There are 321 households producing in the commune, so the amount of waste water discharged in the whole production area can be calculated as follows: $W_{s x}=321 \times 30 \times 70 \%=6741\left(\mathrm{~m}^{3} /\right.$ day $)$. The interview results of some officials in Dong Tho trade village are as follows:

Communities are fully aware of the current pollution problem of the trade village mainly due to the waste water from vermicelli production. All 6 villages have high percentage $(\%)$ of agreement that the cause of water pollution is mainly due to the production of vermicelli (Thong Nhat hamlet: $70 \%$, Doan Ket hamlet: $74 \%$, Tran Phu hamlet: 44\%, Quang Trung hamlet: 50\%, Lam Son hamlet: 58\%). Regarding the harmful effects of pollution, most people realize that the environment is polluted, but about its harm, it seems that the community do not consider it very dangerous, so they have a thought of accepting the fact that "producing and living together with pollution".

On the non-production households, there are two opinions: some are pressing on the discharging issue and some are sympathizing with the producers.

On the part of the producers, they do not want to talk about the pollution aspect or think that it is the general situation of the whole village, there is no other way. They think it is sufficient for households to have their own waste water treatment system (in fact, sedimentation tanks) as the instructions from commune for years.

On the part of some local officials, they are quite concerned, but said that without production, there would be no income and no capital to invest in environmental improvement solutions. At the same time, they said that there have been many research and survey delegations, but until now there is no feasible solution or the cost is too high, they could not implement and they are still passive in resolving the problem, just passively wait for higher level's solution. 
Local authorities are often asked to stop production by neighboring villages and communes.

The proposed solution of the study of Dong Tho trade village waste water characteristics is the treatment technology with biological measure. The first advantage of the solution is that the initial investment cost for the system is not too large, consistent with economic conditions of the production households in Dong Tho commune, which can be developed and replicated in accordance with reality.The treatment system does not require large space to operate because the sedimentation tank, limestone neutral tank, anaerobic treatment tank are built underground; the operation of the system is simple with the common material source. The technical requirements to operate the system are not high, easy for people to apply and it can run in automatic mode [3-5]. System of vermicelli waste water treatment by biotechnology consist of filter tank 1, filter tank 2, sedimentation tank, limstone,air blower, anaerobic tanks, pumping chamber,.. It is shown in Figure 3.

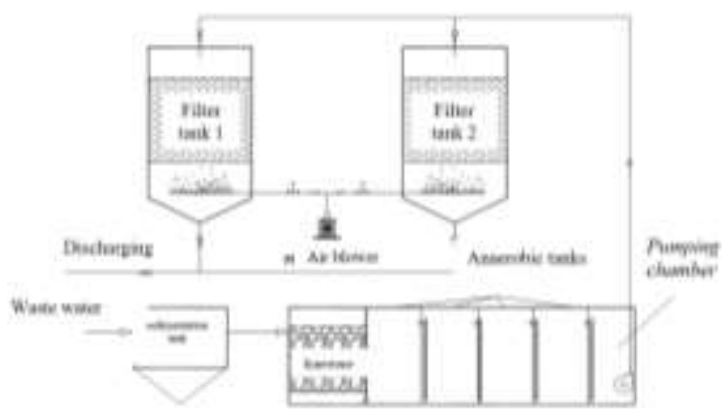

Figure 3. Biotechnology diagram of vermicelli waste water treatment

\section{Conclusions}

Current situation of pollution of production waste water in Dong Tho commune may vary at each village and at different time but the most polluted time is in August and near the Tet holiday because this period are peak production time to serve the needs from the market. The pollution of water environment is expressed through the criteria of BOD, COD, TSS, Total N, Total P, pH ... In the analyzed water samples, the content of TSS, COD and BOD is many times higher than the permitted norms. The air and groundwater in the commune also show signs of spreading pollution due to the spread of impurities from the waste water and surface water. In the face of the ongoing pollution situation in the vermicelli village of Dong Tho commune and the awareness of the people and local authorities, the study proposes a number of management solutions as well as waste water treatment techniques to manage, prevent and minimize pollution of production waste water in Dong Tho commune in order to protect and improve the trade village environment: management solutions, technical solutions, and solutions to promote the role of community in management of production waste water. Especially, community-based management solutions, promoting the role of community and biological measures in waste water treatment are essential.

\section{REFERENCES}

[1]. T. T. O. Pham, Community-based trade village environment management, 3-year project 2014 - 2016, Vietnam Cooperative Union, 2016.

[2]. People's Committee of Dong Tho commune, Summary reports on new rural construction in Dong Tho commune in the period of 2011 2014, 2015, 2016, 2017, Vietnam.

[3]. V. C. Le, Adsorption and ion exchange in water and waste water treatment techniques. Statistical Publishing House, Vietnam, 2002.

[4]. V. C. Le, Integration system in waste water treatment technology - vol.1. Statistical Publishing House, Vietnam, 2014.

[5]. V. C. Le , Integration system in waste water treatment technology - vol. 2. Statistical Publishing House, Vietnam, 2015. 